\title{
Octalysis Audit to Analyze Gamification on Kahoot!
}

Diena Rauda Ramdania ${ }^{1,2, *}$, Dian Sa'adillah Maylawati ${ }^{1,2,3}$, Yana Aditia Gerhana ${ }^{1,4}$, Novian Anggis Suwastika ${ }^{5}$, Muhammad Ali Ramdhani $^{1}$

${ }^{1}$ Department of Informatics, UIN Sunan Gunung Djati Bandung, 40111, Indonesia

${ }^{2}$ System Information Unit, Postgraduate Program, UIN Sunan Gunung Djati Bandung, 40111, Indonesia

${ }^{3}$ Faculty of Information and Communication Technology, Universiti Teknikal Malaysia Melaka, 75150, Malaysia

${ }^{4}$ Department of ICT,Asia E-University, Kuala Lumpur, 43200, Malaysia

${ }^{5}$ School of Computing, Telkom University, Bandung, 40111, Indonesia

\begin{tabular}{l} 
A R T I C L E I N F O \\
\hline Article history: \\
Received: 21 October, 2020 \\
Accepted: 09 January, 2021 \\
Online: 22 January, 2021 \\
\hline Keywords: \\
Game-based learning \\
Gamification \\
Kahoot \\
Octalysis audit \\
Octalysis framework \\
\hline
\end{tabular}

A B S T R A C T

Since its release in 2013, 4.4 billion people around the world have used Kahoot!. Various topics with multiple languages have been made so that there are at least 200 billion games. A very high number for an educational application. Why Kahoot! So interesting? This study aims to analyze the gamification elements found in Kahoot! as a benchmark to create engaging game-based learning in industrial 4.0. The method used is the Octalysis Audit, which examines eight aspects of game psychology: meaning, achievement, empowerment, ownership, social influence, scarcity, unpredictability, and avoidance. The results showed, Kahoot! A value of 441 in Octalysis was obtained. This result shows an excellent balance between positive and negative motivation. Besides, Kahoot also has a balance between Intrinsic and extrinsic motivation.

\section{Introduction}

Game-based learning is not a new thing in education. Educational activists compete to make learning more attractive to increase students' interest in learning a learning material. Specifically, the game is known for its ability to make players feel involved and eager to play it. The enthusiasm in the learning process is an essential factor in obtaining learning outcomes. Often, players/learners are directed to master techniques to reach higher levels. This method is intended to develop skills or to feel pleasure, all of which are intellectual characteristics of motivation in humans [1]. In learning, games are usually applied to evaluate students' understanding of the material they have learned. The evaluation model often collects questions in a quiz, puzzle, questionnaire, etcetera [2,3]. In a game, gamification plays a vital role in increasing motivation [4]. Gamification is defined as the application of game elements in a non-game context [5]. The ingredients in question include at least three things: interface design patterns (badges, levels, leaderboard), game mechanisms,

*Corresponding Author: Diena Rauda Ramdania, +6281394826858, diena.rauda@uinsgd.ac.id www.astesj.com

https://dx.doi.org/10.25046/aj060149 and design principles [6]. The application of gamification can be found in several forms with specific objectives, such as marketing, social media, commerce, corporate marketing, and education [7].

Call it Facebook, Tokopedia, Shopee, Gojek, Waze, etcetera. One application in the world of knowledge that also applies gamification is Kahoot. Kahoot! is game-based learning that has a mission to improve education quality by strengthening the attachment and connectedness between users while playing [8]. Kahoot was released in 2013. This application has been played in more than 200 cities worldwide, with the total number of players reaching 4.4 billion [8], incredible numbers for an application. This study aims to analyze the elements of gamification contained in the Kahoot! Application. This study's research method is the Octalysis Audit, which is a technique to assess the strengths and weaknesses of a product [9]. The assessment was carried out through 8 approaches to the game's psychological side: meaning, achievement, empowerment, ownership, social influence, scarcity, uncertainty, and avoidance. This study allows further research to identify what types of motivation are weak to improve and provide new experiences. This study's results can be applied to the 
application of learning so that teachers or educators continue to innovate in their teaching methods to ensure student motivation in learning sustain, especially in industry 4.0 today, the gaming elements in learning seem relevant.

\section{Literature Review}

In learning, assessment plays an essential role in assessing the process, progress, and student learning outcomes [10]. Several forms of assessment can be formal, informal, written, performance, traditional, authentic, etcetera. Traditionally, written assessments are the most frequent and easy to use. Paperless assessment is starting to be widely used in the 4.0 era. This fact is evidenced by some previous studies that used Kahoot in education for various purposes. For example:

- increasing motivation to learn English [11],

- enriching the ability to think historically on historical subjects [12],

- enhancing learning activities on Islamic studies topics [13],

- facilitating science learning [14],

- studying foreign languages and improve pronunciation [15],

- improving vocabulary performance [16],

- thematic education [17],

- advanced placement Biology class [18],

- formative medical learning assessment tools [19], and

- increasing test scores [20].

The majority of the research results indicate that Kahoot can be appropriately used to assess learning. Besides, the assessment process carried out in Kahoot is simultaneous and transparent in one large group. This condition has proven to be able to increase student motivation and learning outcomes. Toth Aron discovered that Kahoot had a positive effect on students' results and perception of learning. Aron's research results show that students who took part in more Kahoot quizzes tend to reach higher exam marks.

Moreover, they marked more correct answers and less incorrect ones [21]. This research is strengthened by research that states, when combined with active learning and practice, Kahoot! able to improve student learning outcomes [22,23]. Besides learning outcomes, according to the questionnaire, $82.2 \%$ of students stated Kahoot and can also increase student learning motivation [24]. The study results are in line with research that stated that Kahoot enriched student learning quality in the classroom, with the most significant influence on motivation $[25,26]$. A previous study strengthens this research by saying that, based on T-test testing, Kahoot can increase students' motivation and independence by a significant number [27]. Another study found the fact that Kahoot! can have a positive effect on learning performance, classroom dynamics [25], students' and teachers' attitudes, students' anxiety [28], and student engagement [29]. The effect of applying Kahoot to learning is obtained because of gamification [30-32]. This research focuses on analyzing the gamification elements in Kahoot, using a method called Octalysis Audit.

\subsection{Kahoot!}

Kahoot! can be accessed on the page http://www.kahoot.com. Kahoot! provides games that can be played directly in one room, distance learning using video conferencing applications, and learning applications. Several types of user choices are available, starting from free to paid. The difference lies in the features that can be used. In the basic version, game makers can play games personally or via video for ten players. The Basic version offers users to create different types of questions and video hosting for 20 players. The Pro version provides additional game options and allows video hosting for 50 players. Finally, the premium version can host via video for 2000 players.

In the Kahoot! The application, the question maker, and the player have different access. Question makers can create questions independently, choose from the question banks provided, or import from Excel files if they already have them. The type of questions is multiple-choice with four choices, and True or False (Basic version). At the stage of making questions, users can also add images by selecting from the image library, uploading pictures from the device, or attaching a YouTube link. The time limit for working on the questions can be chosen from 5 seconds to 240 seconds. The choice of points in each item can also be arranged with three variants: 0, 1000, and 2000 (Figure 1). When the game maker has finished creating questions, the game can be started by pressing the Done button.

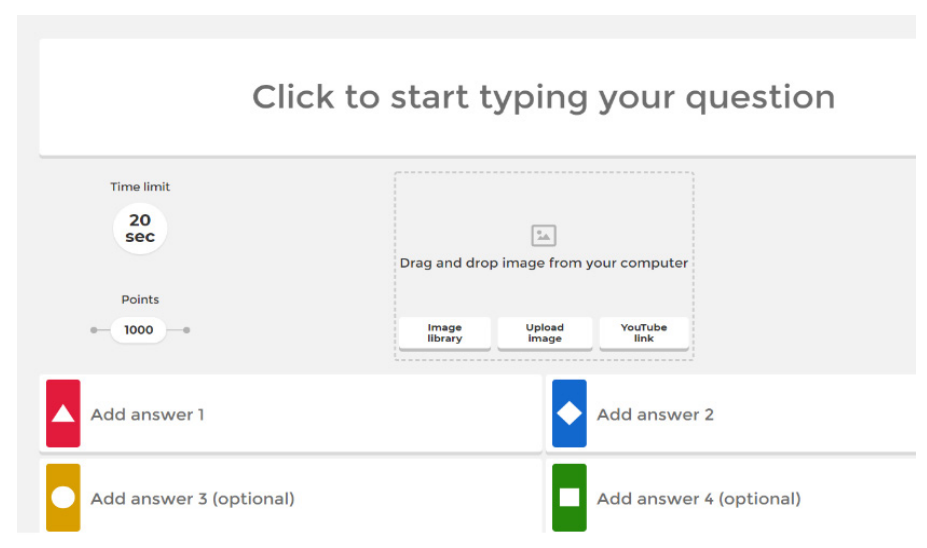

Figure 1: Question-making page on the Kahoot! website

To play the game directly, the question maker must have a tool to display the questions and answer choices on the monitor screen. After the questions are finished, the game can be started by pressing the Play button. Question makers can choose whether individuals or groups will play the game. The interface will then display the PIN that the player must input on the www.kahoot.it page on their respective devices. The player enters a PIN, then comes a nickname on the page. Players who have already joined will appear on the screen. This feature makes it easy for the instructor to monitor how many players have successfully entered. Questions and answer choices will be displayed in front of the screen, whereas on the player's device screen, there are only colors that indicate the answer choices (Figure 2).

\section{Methodology}

The Octalysis framework (Figure 3) was created because in [9] the author recognized the need for tools to help build strategies and analyze gamification implementation. After years of studying game mechanics, Chou concluded that eight core drives motivate someone to do certain activities. Core drives push people in different directions, and not everyone is motivated by the same drive. Visually, Octalysis has an octagonal shape in which the core 
drives are represented in each corner. The drive on the right represents the creative, artistic, and social aspects, while the left's drive represents the logical and intellectual aspects. These sides are referred to as the Left Brain and Right Brain. Besides, he discussed the importance of understanding that this urge supports extrinsic or intrinsic motivation [33].

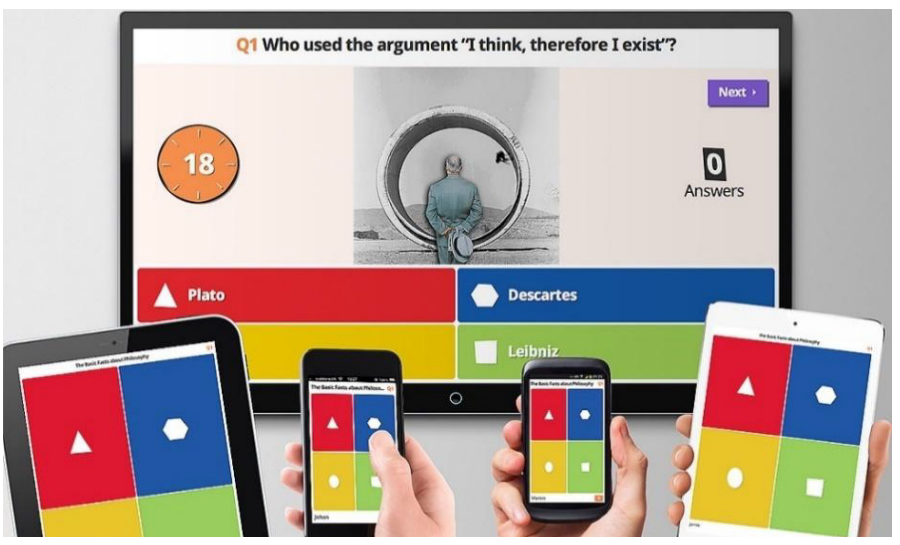

Figure 2: Illustration of Kahoot's interface! when played

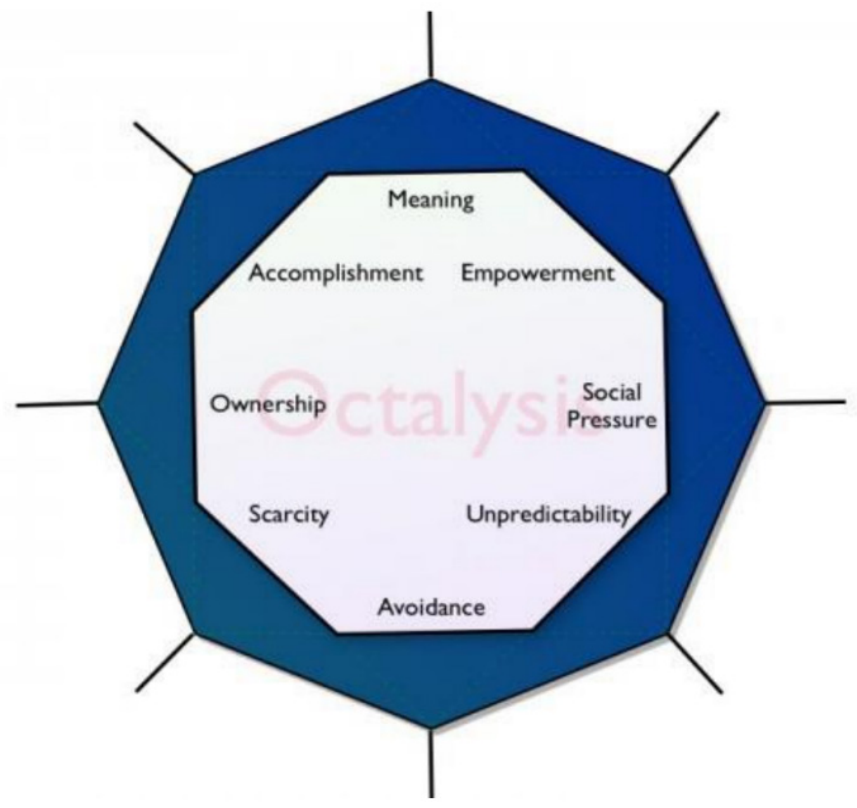

Figure 3: Octalysis Framework

Core drive on the lower side of Octalysis is referred to as Black Hat Gamification, which means negative motivation. This type of encouragement relates to people who are motivated to take specific actions. For example, fear losing because of curiosity about events to come or efforts to achieve things that they cannot have. On the upper side of Octalysis is a positive motivation called White Hat Gamification. This positive core drive motivates individuals through creativity, making them feel secure because of their sense of control and the impression of more significant meaning. Octalysis emphasizes that negative encouragement can inspire motivation as much as positive motivation, but the balance between the two is essential to achieve satisfying and beneficial results.

Octalysis highlights that successful gamification requires consideration of all core drives. The eight-core drives referred to in Octalysis are as follows [34]:
1. Epic Meaning and Calling

At this core, the user is motivated to do something greater than himself or feel chosen to do something. In a game, narration can make this core more pronounced. For example, in the intro of a game, it is said that the world will soon be destroyed, and somehow, the player is chosen as the only person who is qualified to save the world. This core certainly creates excitement and fosters motivation for players to carry out adventures in the game.

Another example is people who contribute to filling content on Wikipedia pages. Someone who feels "called" will be willing to spend hours filling the content on the page, even if not paid.

\section{Development and Accomplishment}

Development and achievement are internal drives to make progress, develop skills, and ultimately overcome challenges. In this core, various kinds of performances are designed, such as points, badges, leaderboards, rewards, and other achievements that players can get.

3. Empowerment of Creativity and Feedback

At this core, users are involved in a creative process to find out different combinations repeatedly. Users not only need a way to express creativity but can also see feedback from players.

\section{Ownership and Possession}

This core is related to the motivation of users because they feel they have something. When a player feels he has something, he will indirectly make what he has better and more.

\section{Social Influence and Relatedness}

This core combines all the social elements that drive a person, such as guidance, acceptance, social responses, friendship, competition, and jealousy. When one player sees an extraordinary friend on a skill or has something unusual, the player will be motivated to reach the same level.

\section{Scarcity and Impatience}

In this core, the player is a drive to want something because he cannot have it. For example: due to a time limit, then the game will restart 2 hours later. The fact that players cannot get things now motivates them to think about it all day long.

7. Unpredictability and Curiosity

In general, these cores are harmless drives to find out what happens next. Uncertainty makes players curious. This core happens when someone is reading a book or watching a movie. They will finish what they started of curiosity about the end of the book or film.

8. Loss and Avoidance

This core drive is based on avoiding something negative to happen. Players will feel that if they do not act immediately, they will lose the opportunity to serve forever. 
Octalysis Audit is carried out by assessing each existing core. To produce an Octalysis score, researchers take how well the subject of analysis is in each core drive. Then assign a number between $0-10$ based on personal judgment, data, and experience flow, then square the number to get a Core Drive score. A score of 10 indicates "How strongly this Core Drive motivates toward the Desired Action." The final Octalysis score will be obtained after adding all 8 Core Drive scores [35].

The sample in this study were 34 lecturers from 2 universities in Indonesia. Samples were selected randomly because all individuals in the population singly or together are given the same opportunity to be selected as sample members. Thus, the research results will be more objective. Lecturers, who were the research sample, had used Kahoot more than 15 times. As many as 52.9\% admitted to using Kahoot for lectures, $41.2 \%$ used it for workshops, $31.4 \%$ for seminars, the rest for other purposes. Survey respondents were asked to provide an assessment both as a question maker and a player. The research instrument was in the form of 12 statements arranged according to the eight cores is Octalysis. The assessment given by respondents is subjective based on the experiences they have experienced. Each statement has a Likert scale from 0-10, according to the Octalysis Audit assessment. Table 1 below shows the instruments in this study.

Table 1: Research Instrument

\begin{tabular}{|c|c|c|}
\hline No & Statement & Core No \\
\hline 1 & Kahoot encouraged me to contribute to it & 1 \\
\hline 2 & $\begin{array}{l}\text { Kahoot has features such as points, badges, } \\
\text { scoreboards, rewards, and podiums }\end{array}$ & 2 \\
\hline 3 & $\begin{array}{l}\text { Kahoot encouraged me to try repeatedly and } \\
\text { make different combinations when making } \\
\text { questions }\end{array}$ & 3 \\
\hline 4 & I can see the feedback given by the players & 3 \\
\hline 5 & $\begin{array}{l}\text { I feel that I have to defend and increase the } \\
\text { points I get while playing Kahoot }\end{array}$ & 4 \\
\hline 6 & $\begin{array}{l}\text { When I was a player, I felt proud when other } \\
\text { players applauded when my name appeared } \\
\text { on the Scoreboard / Podium }\end{array}$ & 5 \\
\hline 7 & $\begin{array}{l}\text { If my name does not appear on the } \\
\text { Scoreboard, I have to pursue it in the next } \\
\text { question }\end{array}$ & 5 \\
\hline 8 & $\begin{array}{l}\text { Often the participants asked me to repeat the } \\
\text { game when it was finished }\end{array}$ & 6 \\
\hline 9 & $\begin{array}{l}\text { I was wondering how many questions I had to } \\
\text { answer }\end{array}$ & 7 \\
\hline 10 & $\begin{array}{l}\text { Every } 1 \text { question is answered successfully, I } \\
\text { always wonder whether my name is in the top } \\
5 \text { or not }\end{array}$ & 7 \\
\hline 11 & $\begin{array}{l}\text { For me, the most important thing is to answer } \\
\text { quickly even if it is wrong }\end{array}$ & 8 \\
\hline 12 & $\begin{array}{l}\text { For me, the most important thing is to answer } \\
\text { correctly even though it takes a long time }\end{array}$ & 8 \\
\hline
\end{tabular}

\section{Result and Discussion}

\subsection{Epic Meaning and Calling}

A total of 11 respondents gave a score of 8 for the statements on this core (Figure 4). Epic meaning and calling can be done when the user, for example, fills in a question bank. The question bank provided by Kahoot! allows users to search for problems with specific themes that have been created by other users (Figure 5). Fellow users around the world can benefit from each other. This feature is related to the core meaning in Octalysis, where users can feel motivated to make various questions for themselves and others. This calling is in line with previous studies, which stated that student motivation increased after using Kahoot! [11]. The average score for this core is 6.74 .

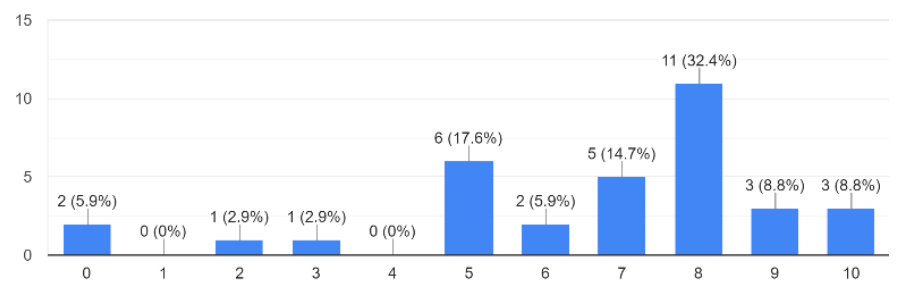

Figure 4: Epic Meaning and Calling response result

\section{Question bank}

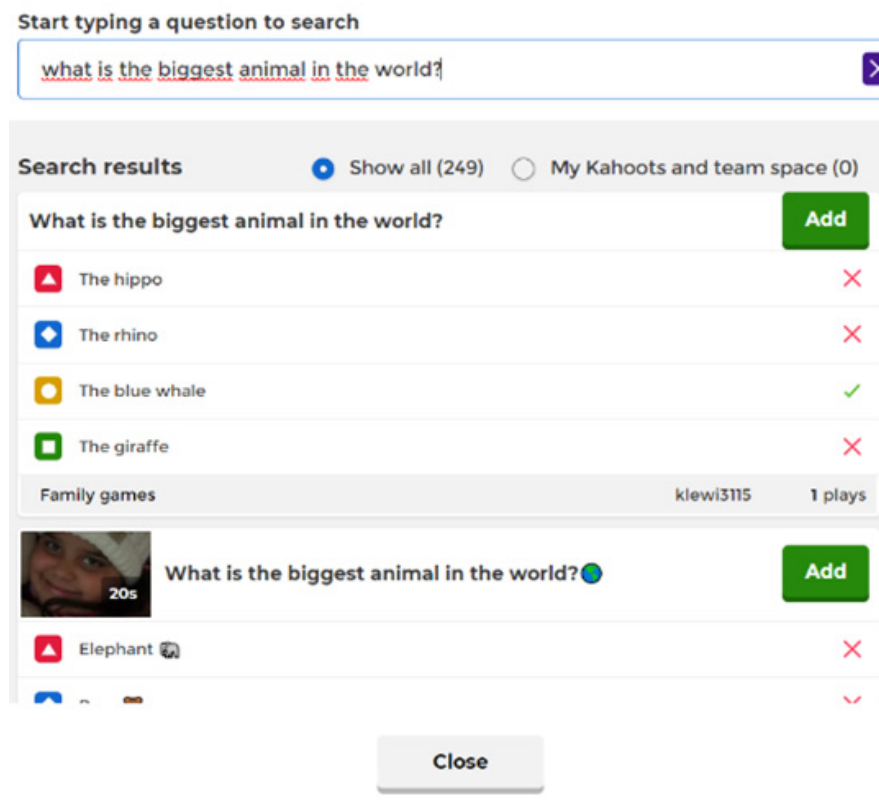

Figure 5: The question bank on the Kahoot! Page

\subsection{Accomplishment}

For each question answered, Kahoot can display the correct answer, and the Scoreboard contains the five highest-ranked players and their respective points (Figure 6a). This feature certainly raises pride for players whose names are displayed on the Scoreboard. The three best players will be shown their names with a podium interface at the end of the game. The back-sound also supports it as if the player is on a real podium (Figure 6b).

At this core, $75 \%$ of respondents gave a score of 8 and 10 . This result indicates that respondents have understood that Kahoot has gamification features, such as point, Scoreboard, reward, and podium. The average score obtained from the statement on this core is 8.67.

\subsection{Empowerment of Creativity and feedback}

An exciting game requires creativity from the creator. To not be monotonous, question makers can add questions that are not too 
serious in the middle of the game. For example, by making a problem that displays a photo of one of the players, then questioning what the player is doing? This question will make the game more interesting. However, of course, creativity here is relatively dependent on the question maker. When respondents were given the statement, "Kahoot encouraged me to make different combinations when making questions." $50 \%$ gave a score of 8 and above. The survey results show a balanced answer, depending on the creativity of the question maker.

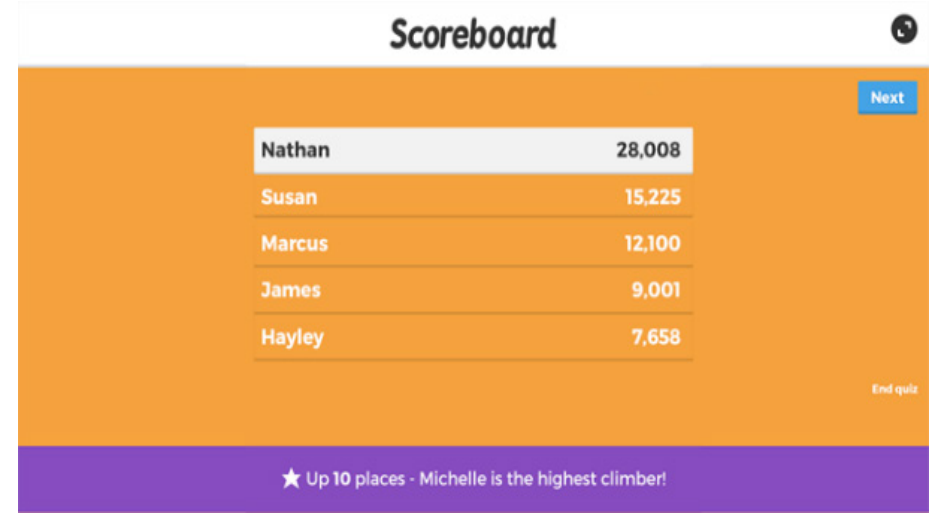

(a)

\section{Top scorers!}

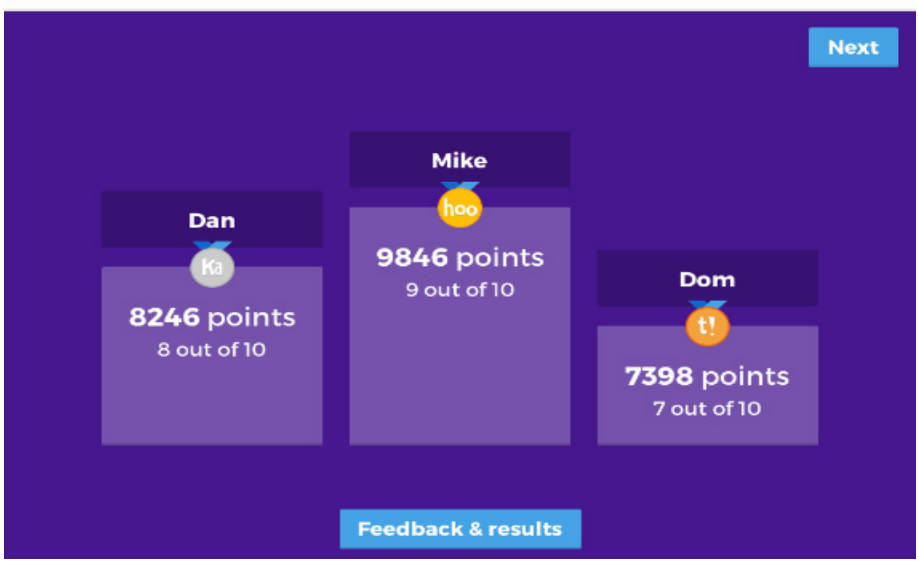

(b)

Figure 6: (a) Scoreboard Interface (b) Podium Interface

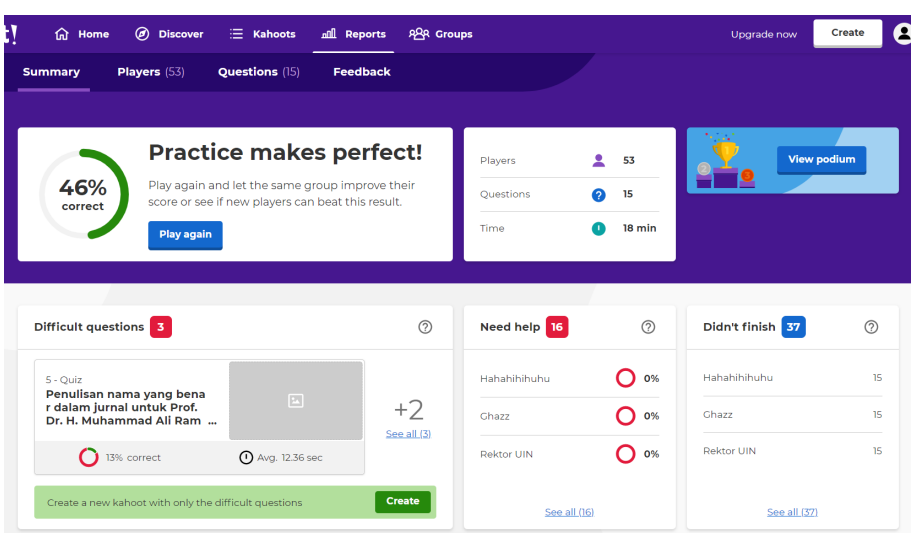

Figure 7: Summary of the Kahoot! Page

The question maker can see player feedback at the end of the game. One of the new features provided by Kahoot is the
Summary, which contains a summary of the games that have been performed. Figure 7 shows the Kahoot Summary, containing the number of players, the percentage who answered correctly, the number of questions, the time, the most difficult questions, to the player's status. This player status includes whoever needs help, players who have not finished the game to the end, and the podium. This new feature makes it very easy for question makers to review the game as a whole.

\subsection{Ownership and Possession}

One of the exciting gamification elements of Kahoot is the point. Points for each question in Kahoot can be varied, starting from 0,1000 , and 2000 . The faster and more precise the player answers the question, the higher the score obtained. With the scoreboard feature, players can see how many points they have. If the player's name is on the Scoreboard, it will undoubtedly make them maintain a high position so that no one beats him.

The importance of the points obtained attracted $35.3 \%$ of respondents to give a value of 10 to statement number 5. This fact shows that the respondents strongly agree with this statement. Apart from getting points, more than $84 \%$ of respondents also agreed to retain their points when playing Kahoot. These survey results are in line with the core ownership and position in Octalysis, where the players try hard to defend the points they get.

\subsection{Social Influence and Relatedness}

One of the gamification elements that have a strong social influence is the Scoreboard and the Podium. Other players will usually congratulate or applause when a player's name appears on the Scoreboard or Podium. Events like this bring pride to these players. A total of 26 survey respondents gave a score of 8-10 concerning the statement, "I feel proud when other participants applaud when my name appears on the Scoreboard / Podium."

Conversely, this social influence also motivates players whose names do not appear on the Scoreboard. A player whose name is not on the Scoreboard will be motivated to catch up and make his points higher. A total of 29 respondents strongly agreed to pursue other participants' points when their names did not appear on the Scoreboard. This sense provides the motivation that is in line with the core of social influence and relatedness.

\subsection{Scarcity and Impatience}

Based on experience, some of the respondents said that often when finished playing Kahoot, the player asks the host to repeat the game. Motivation to get better grades makes players want the same game a second time. However, some respondents admitted that they did not want to repeat the game because the order of the questions displayed would be precisely the same as before. In this core statement, the average score is 7.9 (Figure 8).

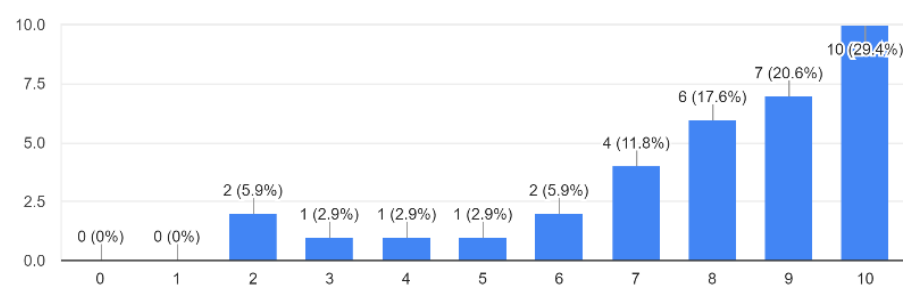

Figure 8: Scoring for the Scarcity cores 


\subsection{Unpredictability and Curiosity}

More than 60 percent of our respondents are intrigued as to how many questions they have to raise. Although, in the gameopening, a justification is given for the number of questions to be played (Figure 9). Another thing that triggers the players' curiosity is to find out whether he entered the Scoreboard or the podium at the end of the game (Figure 10). A scoreboard will appear that all participants have answered every 1 question. This core gets an average score of 8.12 points.

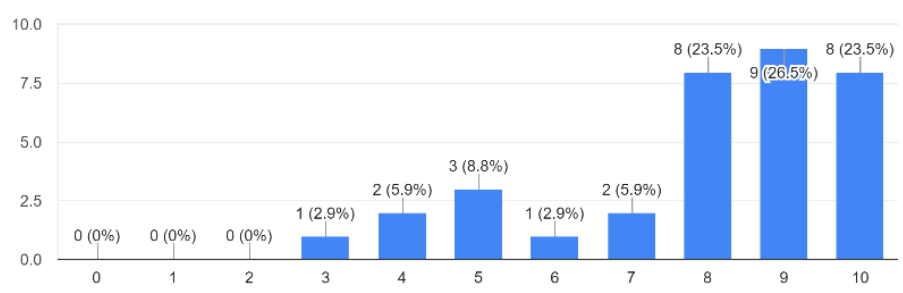

Figure 9: Score given by respondents regarding curiosity about the number of questions

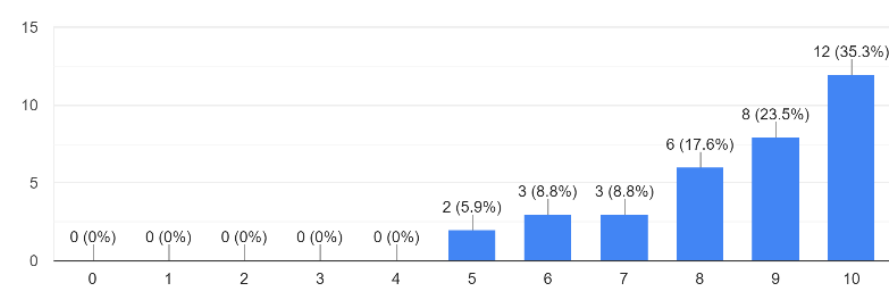

\subsection{Loss and Avoidance}

The last core in Octalysis Framework is related to the speed of players in answering questions on Kahoot. Because the time to answer questions can be varied, players certainly do not want to miss answering questions because they run out of time. This feeling will harm the players because they do not get the point. Conversely, if too fast but other players can replace the wrong answer, the ranking of players.

Table 2: Average score for every core

\begin{tabular}{|c|l|c|}
\hline No & Core Aspect & Average \\
\hline 1 & Epic Meaning and Calling & 6.74 \\
\hline 2 & Development and Accomplishment & 8.67 \\
\hline 3 & Empowerment of Creativity and Feedback & 7.5 \\
\hline 4 & Ownership and Possession & 8.41 \\
\hline 5 & Social Influence and Relatedness & 8.30 \\
\hline 6 & Scarcity and Impatience & 8.35 \\
\hline 7 & Unpredictability and Curiosity & 8.12 \\
\hline 8 & Loss and Avoidance & 6.24 \\
\hline
\end{tabular}

On this core, we ask what is most important for players. A total of 5.3 average scores was obtained for the statement to answer quickly, even though it was wrong. The statement chose the right answer, even though it took a long time to get an average value of 7. This result shows that each respondent has different priorities. Some respondents choose the time, and some are more careful even though they lose much time.
Based on the respondents' answers for each Octalysis core, we add up each point obtained, then divide by the number of respondents to obtain each statement's average value. The average value is shown in Table 2 .

\subsection{Octalysis Score}

The values entered in the Octalysis tool provide only round values [36]. Therefore, we take the numbers that come before the comma. Based on the research results, the value obtained was 441 . Kahoot is considered to have a balance between White Hat and Black Hat drives. This result marks Kahoot balancing the positive and negative motivations of the player. Besides, the right brain balance and the left brain is also considered quite good, which indicates Kahoot! application has a proper balance between Intrinsic and Extrinsic Motivation. An overview of Octalysis Kahoot's audit analysis present in Figure 11.
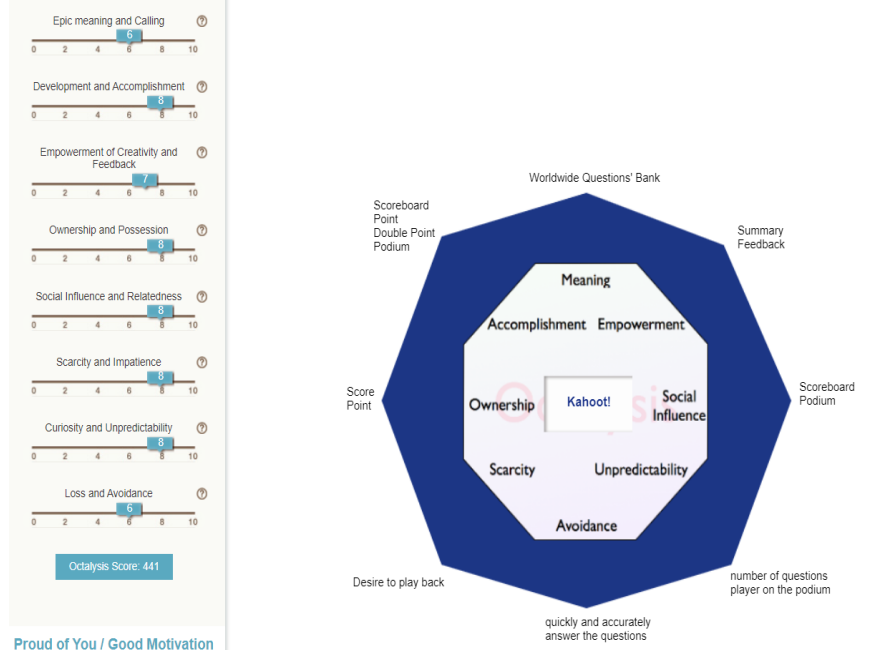

Figure 11: Kahoot! 's Octalysis audit result

Even though it is considered quite reasonable, according to the Octalysis tool, some of our respondents provide suggestions for Kahoot. The suggestions given include minus points, questions raised on players' gadgets, opportunities to correct wrong answers, open camera facilities, to custom music. These suggestions will certainly make Kahoot better and more attractive to use in learning.

\section{Conclusion}

Has been analyzed a game-based game application called Kahoot! by using the Octalysis Audit method. The score on the form accumulated by survey based on eight core drives on Octalysis. Based on research, a final value of 441 was obtained in the Kahoot application. This outcome is Kahoot! It is a balance in terms of motivation, both positively and negatively. The outcome also shows that Kahoot! has intrinsic and extrinsic motivation. Therefore, Kahoot! can be used as the right learning media to make similar games. Researchers have recommended some suggestions to improve Kahoot! better. Such as: providing tips to make the game more interesting, providing a random feature about the problem, and providing a minus point feature if the answer is wrong.

\section{Conflict of Interest}

The authors declare no conflict of interest. 


\section{Acknowledgment}

Authors wishing to acknowledge the Postgraduate Program of UIN Sunan Gunung Djati Bandung that supports and funds this research publication.

\section{References}

[1] R.E. White, "The Power Of Play: A Research Summary on Play and Learning," Smart Play, 15-25, 2013.

[2] D.R. Ramdania, M. Irfan, S.N. Habsah, C. Slamet, W. Uriawan, K. Manaf, "Fisher-Yates and fuzzy Sugeno in game for children with special needs," Telkomnika (Telecommunication Computing Electronics and Control), 18(2), 879-889, 2020, doi:10.12928/TELKOMNIKA.V18I2.14906.

[3] D.R. Ramdania, M. Harika, S. Rahmadika, G.G. Azmiana, "The Use of Relations and Functions Games Based on Balanced Design in Mathematics Subjects to Improve Student Learning Outcomes," in Journal of Physics: Conference Series, IOP Publishing: 12069, 2019.

[4] S. Deterding, "Gamification: designing for motivation," Interactions, 19(4), $14-17,2012$

[5] S. Deterding, M. Sicart, L. Nacke, K. O'Hara, D. Dixon, Gamification: Using game design elements in non-gaming contexts, 2011, doi:10.1145/1979742.1979575.

[6] B. Liu, "Uncertainty theory: A branch of mathematics for modeling human uncertainty," Studies in Computational Intelligence, 300, 1-361, 2010, doi:10.1007/978-3-642-13959-8_1.

[7] Y. Chou, Gamification Examples: the fully comprehensive list (2019), 2019.

[8] Kahoot!, About Kahoot! | Company History \& Key Facts, 2018.

[9] Y.-K. Chou, Actionable gamification: Beyond points, badges, and leaderboards, 2016, doi:10.1017/CBO9781107415324.004.

[10] I. Tosuncuoglu, "Importance of Assessment in ELT," Journal of Education and Training Studies, 6(9), 163, 2018, doi:10.11114/jets.v6i9.3443.

[11] E.T. Tsani, Using Kahoot! as games-based E-Learning to enhance students' English learning motivation, 2019.

[12] R. Fauzan, "Pemanfaatan Gamification Kahoot.it Sebagai Enrichment Kemampuan Berfikir Historis Mahasiswa pada Mata Kuliah Sejarah Kolonialisme Indonesia (Utilization of Kahoot.it Gamification as Enrichment of Students' Historical Thinking Abilities in the Historical C," Prosiding Seminar Nasional Pendidikan FKIP UNTIRTA, 2(1), 257, 2019.

[13] H. Fauzih, Gamification: A Case Study for Evaluating the Performance of Employees | KHASKHELI | Sindh University Research Journal - SURJ (Science Series), 2019.

[14] K.E. Cameron, L.A. Bizo, "Use of the game-based learning platform KAHOOT! to facilitate learner engagement in animal science students," Research in Learning Technology, 27, 2019, doi:10.25304/rlt.v27.2225.

[15] N. Yürük, "Edutainment: Using Kahoot! As A Review Activity in Foreign Language Classrooms," Journal of Educational Technology and Online Learning, 2(2), 89-101, 2019, doi:10.31681/jetol.557518.

[16] M. Mansur, M. Mansur, D. Fadhilawati, "Applying Kahoot to Improve the Senior High School Students' Vocabulary Achievement," VELES Voices of English Language Education Society, 3(2), 164-173, 2019.

[17] A.R. Hakim, S. Rahayu, R. Affida, "Kahoot on Thematic Learning," in Journal of Physics: Conference Series, 2019, doi:10.1088/17426596/1381/1/012035.

[18] S.M. Jones, P. Katyal, X. Xie, M.P. Nicolas, E.M. Leung, D.M. Noland, J.K. Montclare, "A 'KAHOOT!'Approach: The Effectiveness of Game-Based Learning for an Advanced Placement Biology Class," Simulation \& Gaming, 50(6), 832-847, 2019.

[19] M.A.A. Ismail, A. Ahmad, J.A.M. Mohammad, N.M.R.M. Fakri, M.Z.M. Nor, M.N.M. Pa, "Using Kahoot! as a formative assessment tool in medical education: A phenomenological study,” BMC Medical Education, 19(1), 230, 2019, doi:10.1186/s12909-019-1658-z.

[20] P.A. Baszuk, M.L. Heath, "Using Kahoot! to increase exam scores and engagement," Journal of Education for Business, 2020, doi:10.1080/08832323.2019.1707752.

[21] Á. Tóth, P. Lógó, E. Lógó, "The Effect of the Kahoot Quiz on the Student's Results in the Exam," Periodica Polytechnica Social and Management Sciences, 27(2), 173-179, 2019. https://doi.org/10.3311/PPso.12464

[22] I.L. Aldana, "The Effects of Review Games Using Kahoot! On Students' Quiz Scores.," Online Submission, 2020.

[23] S. Chera, "Analyzing the impact of recurrent Kahoot tests on student performance," 2020.

[24] R.D. Mada, A. Anharudin, "How Online Learning Evaluation (Kahoot) Affecting Students' Achievement and Motivation (Case Study on it
Students)," International Journal for Educational and Vocational Studies, 1(5), 422-427, 2019.

[25] N. Kletnikov, O. Popovski, A. Tomova, "Kahoot! foster students' engagement, enhance classroom dynamics, assess and improve overall students' learning," Proceedings of Papers, 24, 2019.

[26] L.S.L. Purba, E. Sormin, N. Harefa, S. Sumiyati, "Effectiveness of use of online games kahoot! chemical to improve student learning motivation," Jurnal Pendidikan Kimia, 11(2), 57-66, 2019.

[27] M. Izzati, H. Kuswanto, "Pengaruh model pembelajaran blanded learning berbantuan kahoot terhadap motivasi dan kemandirian siswa (The influence of the kahoot-assisted blended learning model on students' motivation and independence)," EDUMATIC: Jurnal Pendidikan Informatika, 3(2), 68-75, 2019

[28] A.I. Wang, R. Tahir, "The effect of using Kahoot! for learning-A literature review," Computers \& Education, 149, 103818, 2020.

[29] Y. Benhadj, M. El Messaoudi, A. Nfissi, "Investigating the Impact of Kahoot! on Students' Engagement, Motivation, and Learning Outcomes: Ifrane Directorate as a case study," International Journal of Advance Study and Research Work, 2(6), 2581-5997, 2019.

[30] O. Baydas, M. Cicek, "The examination of the gamification process in undergraduate education: a scale development study," Technology, Pedagogy and Education, 28(3), 269-285, 2019.

[31] M.L. Pertegal-Felices, A. Jimeno-Morenilla, J.L. Sánchez-Romero, H. Mora-Mora, "Comparison of the Effects of the Kahoot Tool on Teacher Training and Computer Engineering Students for Sustainable Education," Sustainability, 12(11), 4778, 2020.

[32] N.P.A. Resmayani, I.N.T.D. Putra, "Gamification: Using Kahoot! to Make Students Love the Class from the Very Beginning," Linguistics and ELT Journal, 7(1), 10-18, 2020.

[33] J. Landsell, "Towards a Gamification Framework: Limitations and opportunities when gamifying business processes," 2016.

[34] Y.-K. Chou, "Actionable gamification: Beyond points, badges, and leaderboards," Octalysis Media, 1-151, 2016 , doi:10.1017/CBO9781107415324.004.

[35] Y. Chou, Octalysis: Complete Gamification Framework - Yu-kai Chou, 2013.

[36] Y. Chou, Octalysis / Gamification Building Developing Online Tool - by Yukai Chou, Dec. 2020. 